\title{
Digital literacy as a part of continuing education library efforts
}

\author{
Vrana, Radovan
}

Source / Izvornik: MIPRO 2020 proceedings, 2020, 801 - 806

Conference paper / Rad u zborniku

Publication status / Verzija rada: Accepted version / Završna verzija rukopisa prihvaćena za objavljivanje (postprint)

Permanent link / Trajna poveznica: https://urn.nsk.hr/urn:nbn:hr:131:822772

Rights / Prava: Attribution-NonCommercial-NoDerivatives 4.0 International/ImenovanjeNekomercijalno-Bez prerada 4.0 međunarodna

Download date / Datum preuzimanja: 2023-04-26

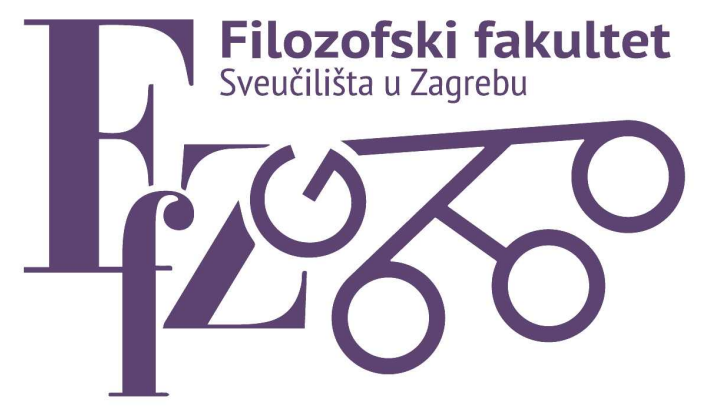

Repository / Repozitorij:

ODRAZ - open repository of the University of Zagreb

Faculty of Humanities and Social Sciences
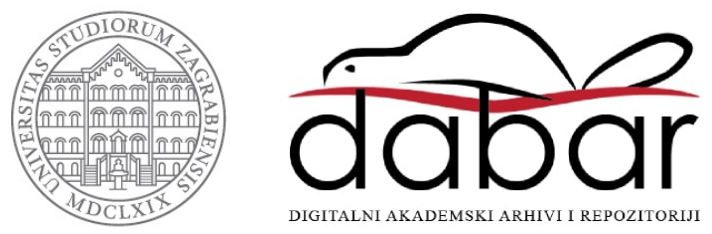


\title{
Digital literacy as a part of continuing education library efforts
}

\author{
R. Vrana \\ Faculty of Humanities and Social Sciences, University of Zagreb, Zagreb, Croatia \\ rvrana@ffzg.unizg.hr
}

\begin{abstract}
As the information technology (IT) continues being a part of everyone life, or, at least, of everyone being in position to use any device connected to some type of a communication network including mobile networks, it has become extremely critical for a person to become digitally literate. Younger generations receive education in digital literacy education during their schooling, while adults are frequently lacking such competences once they leave formal education and find employment. Public libraries aim to bridge the digital divide and provide access to critical information and activities to anyone interested in acquisition of knowledge and skills for use of IT and use of digital information sources. The purpose of the research conducted in form of a survey was to confirm an important role of public libraries as places of informal and continuing education in digital literacy in an environment different from schools and universities (places of formal education). The research results in this paper show that public libraries are active facilitators and educational partners in introducing digital literacy to their users. In spite of some obstacles, public libraries remain determined to provide access to critical information sources and activities, which would lead to greater proficiency in digital literacy.
\end{abstract}

Keywords - digital literacy; public library; continuig education; Croatia

\section{INTRODUCTION}

Being digitally literate is a necessary state in the modern society as it changes constantly in its every segment, and these changes require proficiency in different literacies including digital literacy. Those who are not digitally literate will be at a distinct disadvantage as the world is being significantly impacted on by digital technologies [1]. Each new generation of users of digital devices grew up with a different device: games consoles, the Internet and subsequently the smart phone [2]. Each of these technologies has left its mark on life of individuals and development of their abilities to be active workforce and to contribute to the development of society.

The need for digitally literate workforce has become more evident as the development of technology speeds up and as the technology influences development of the society. Rapid changes in the world are putting pressure on already challenged labour markets in many countries [3]. According to the same author, Technology is fundamentally altering the employment relationship and each individual seeking employment should reskill himself or herself. The reskilling revolution aims to provide skills to 1 billion workers within the next five years [3]. Schools and universities around the world are aware of this situation and they change their study programmes according to the needs of the labour market. While this activity might seem logical (and it is) and obvious (still is), it happens over time, and sometimes too slowly (in the eyes of employers). The labour market demands students to have digital skills in order engage better not only with their learning but also contribute to a rapidly changing work environment after their graduation [4]. The employers also expect that their employees will continue their education in the coming years and contribute to the development of the company or organization they work for.

\section{DIGITAL LITERACY}

Digital literacy can be defined differently according to different sources. According to The American Library Association [5], digital literacy is the ability to use information and communication technologies to find, evaluate, create, and communicate information, requiring both technical and cognitive skills. Another definition offers another view of the matter: Digital literacy can be defined as a social practice that involves reading, writing and multimodal meaning-making through the use of a range of digital technologies. It describes literacy events and practices that involve digital technologies, but which may also involve non-digital practices [2]. A digitally literate person: possesses the variety of skills - cognitive and technical-required to find, understand, evaluate, create, and communicate digital information in a wide variety of formats; is able to use diverse technologies appropriately and effectively to search for and retrieve information, interpret search results, and judge the quality of the information retrieved; understands the relationships among technology, lifelong learning, personal privacy, and appropriate stewardship of information; uses these skills and the appropriate technologies to communicate and collaborate with peers, colleagues, family, and on occasion the general public; uses these skills to participate actively in civic society and contribute to a vibrant, informed, and engaged community [6]. Digital literacy is usually talked or written about in terms of skills sets. Digital marketing institute [7] listed 10 digital skills educators should offer in their portfolio to meet student and industry needs: social media, search engine marketing, analytics, content marketing, email, mobile connectivity, strategic planning, social selling, pay-perclick marketing (PPC), video. Another document What are digital skills? A comprehensive definition for modern 
organisations [8] lists another set of digital skills: fluency in inputting information digitally on a range of devices and software packages; manipulating data into less cognitively-taxing and more understandable form; confidence moving between devices and using time equally; reproducing and manipulating different types of digital information; research, analysis and search skills; understanding how information can be effectively and ethically used and manipulated; confident and competent transacting via digital channels while being aware of the limitations; effectively using and managing digital troubleshooting mediums; setting up, modifying and personalising digital devices and software; positive, sceptical and safe use of digital channels, devices and information; an awareness of how human beings consume content in digital mediums; fluency in participating in social channels; being able to manage virtual interpersonal relationships; an understanding of what digital collaboration looks like; an open mind to future digital developments; an awareness of digital trends in your (and related) domains; comfortable with combining experiential and formal learning for new technologies; how to be data-driven (and the limitations of being datadriven); how automation can help and hinder operational excellence; know-how and experience in stopping technology from controlling you. Acquisition and possession of required digital skills qualifies a person for existing jobs and prepares him / her for new and yet non existing jobs in emerging sectors so people with more advanced digital skills can take advantage of an even wider range of opportunities brought about by ongoing advances in digital technologies, platforms, and devices [9]. Digital skills are important because of the changing nature of the work environment, including the sharp growth in the use of freelancers and people participating in the gig economy, as well as broader structural changes profoundly impacting future jobs [10].

\section{DIGITAL LITERACY AND LIBRARIES}

Libraries in general and public libraries in particular around the world offer different types of activities including those related to acquisition of knowledge and skills in digital literacy. Information sources on the Internet list different skills classified as digital skills in different areas of market. If individuals cannot acquire these skills during their formal education, they start seeking additional education elsewhere including the Internet as a virtual place of cheap education and public libraries as physical spaces equipped and ready to facilitate informal education. Libraries have always had a crucial role in the dissemination and application of knowledge and in providing a place for (informal) lifelong learning [11]. Public libraries are place of continuing education i.e. education for adults in a variety of subjects, most of which are practical, not academic [12]. Today, public libraries offer a variety of information sources, printed and digital as well as a plethora of activities aimed at different user groups and meeting their needs for knowledge. Digital literacy is a topic of common interest to all public libraries wishing to facilitate better use of their existing sources in order to contribute actively to the development of society seeking skilful individuals who will fit into the industry 4.0 framework. Knowledge and skills about digital technology are transferred in public libraries in different forms: lectures, workshops, demonstrations etc.

\section{RESEARCH}

The purpose of the research was to confirm an important role of public libraries in Croatia as places of informal and continuing education in digital literacy in an environment different from schools and universities (places of formal education). The aim of the research is to collect data about sources and activities offered in public libraries related to education in digital literacy. The research sample was formed from the data available at the portal of public libraries in Croatia at https://www.knjiznica.hr/. Total of 220 public libraries were selected as the sample in this research. The online survey consisting of 15 questions was chosen as a research method because of the geographically dispersed respondents and low cost of carrying out the research. The first part of the survey aimed at collecting data about carrying out digital literacy activities in public libraries in Croatia, including types of activities, their frequency, and financing of such activities. The next part of the survey included topics in digital literacy carried out in public libraries in Croatia. The final part of the survey included questions about ways of carrying out digital literacy activities and abilities of public libraries to offer such activities to their users.

All identified public libraries in Croatia were invited to participate in the research on January 2nd 2020 by sending e-mail invitations to their e-mail addresses. Total of 14 invitation were not delivered due to technical issues on the side of public libraries which gives total of 206 libraries to which invitations were successfully delivered by e-mail. The research was closed on January $17^{\text {th }} 2020$. The total of 95 public libraries in Croatia participated in the research which is $46,11 \%$ of the total number of public libraries to which invitations were successfully delivered.

\section{RESULTS AND COMMENTS}

In the introductory question (Q1), public libraries were asked to confirm whether they have activities related to digital literacy as part of their annual plans of activities. Of the total 95 libraries, $71(74,7 \%)$ public libraries confirmed that they included digital literacy related activities in their annual plans and 24 of them $(25,3 \%)$ denied it. The overall result is positive which suggests that public libraries has accepted this type of activity and have added them to the already long lists of activities available to library users in public libraries in Croatia.

Q2. What activities carried out in your public libraries were related to digital literacy? The total of 23 predefined answers were offered.

Table 1. Activities carried out in public libraries related to digital literacy $(\mathrm{N}=95)$ (multiple answers possible)

\begin{tabular}{|l|c|c|}
\hline \multicolumn{1}{|c|}{ Searching the Internet } & $\mathrm{N}$ & $\%$ \\
\hline Communication by use of digital technology & 88 & 92,63 \\
\hline E-mail & 75 & 78,95 \\
\hline Data analysis and search & 67 & 70,53 \\
\hline
\end{tabular}




\begin{tabular}{|l|c|c|}
\hline Problem solving by use of digital technology & 65 & 68,42 \\
\hline Use of social media & 65 & 68,42 \\
\hline Understanding of new digital trends & 61 & 64,21 \\
\hline Presentation design & 59 & 62,11 \\
\hline Safe use of electronic devices and information sources & 59 & 62,11 \\
\hline Word processing & 58 & 61,05 \\
\hline Data processing & 54 & 56,84 \\
\hline Digital data inputting & 52 & 54,74 \\
\hline Graphical material processing & 48 & 50,53 \\
\hline Understanding of technology management & 47 & 49,47 \\
\hline Manipulation of different types of data & 45 & 47,37 \\
\hline Ethical use of information & 44 & 46,32 \\
\hline Collaboration in digital environment & 44 & 46,32 \\
\hline $\begin{array}{l}\text { Understanding how information are transferred in } \\
\text { communication channels }\end{array}$ & 42 & 44,21 \\
\hline Video editing & & \\
\hline Connecting PC to the Internet & 40 & 42,11 \\
\hline $\begin{array}{l}\text { Management of interpersonal relations in digital } \\
\text { environment }\end{array}$ & 37 & 38,95 \\
\hline Ability of using multiple electronic devices & 35 & 36,84 \\
\hline Setting of electronic devices and software & 32 & 33,68 \\
\hline & 26 & 27,37 \\
\hline
\end{tabular}

Answers to this question were formed mostly from the available literature on digital literacy and activities that are directly related to increasing proficiency in digital literacy. Activities in Table 1. indicate the need of the respondents for digital communication, use of digital technology for problem solving and data analysis and search. More traditional activities like word processing or video editing are not so highly ranked anymore suggesting that the respondents' priorities in knowledge have shifted.

\section{Q3. Types of education activities related to digital} literacy offered by public libraries.

Table 2. Types of education activities related to digital literacy offered by public libraries. ( $\mathrm{N}=94)$ (multiple answers possible)

\begin{tabular}{|l|c|c|}
\hline \multicolumn{1}{|c|}{ by public libraries. $(\mathrm{N}=94)$ (multiple answers possible) } \\
\hline Workshops & $\mathrm{N}$ & $\%$ \\
\hline Lectures & 74 & 78,72 \\
\hline Demonstrations & 42 & 44,68 \\
\hline We don't offer any educational activity & 17 & 18,09 \\
\hline Tribunes & 16 & 17,02 \\
\hline Panels & 7 & 7,45 \\
\hline Other & 3 & 3,19 \\
\hline
\end{tabular}

The Table 2. shows two distinctive activities - workshops and lectures - carried out in public libraries according to their abilities to carry out such activities, At the same time the results suggest popularity of these two activities as public libraries wouldn't be offering them without users' interest for them. Sixteen libraries do not offer any of suggested activities and there were 3 answers "Other": individual work with library users, training for use of Ecitizen system, and help to users in use of PCs.

Q4 Information sources related to digital literacy offered in public libraries.

Table 3. Information sources related to digital literacy offered in public libraries. $(\mathrm{N}=94)$ (multiple answers possible)

\begin{tabular}{|l|c|c|}
\hline & $\mathrm{N}$ & $\%$ \\
\hline Written printed guidelines / tutorials & 47 & 50,00 \\
\hline Written digital guidelines / tutorials & 25 & 26,60 \\
& & \\
\hline
\end{tabular}

\begin{tabular}{|l|c|c|}
\hline $\begin{array}{l}\text { Multimedia Web tutorial of the Web page } \\
\text { of the library }\end{array}$ & 25 & 26,60 \\
\hline $\begin{array}{l}\text { Multimedia Web tutorial of the Web page } \\
\text { of another institution or library }\end{array}$ & 18 & 19,15 \\
\hline Quiz & 12 & 12,77 \\
\hline $\begin{array}{l}\text { Video about digital literacy related } \\
\text { activities }\end{array}$ & 9 & 9,57 \\
\hline $\begin{array}{l}\text { We don't offer any information sources } \\
\text { related to digital literacy }\end{array}$ & 8 & 8,51 \\
\hline Other & 1 & 1,06 \\
\hline
\end{tabular}

This question aimed at discovering types of information sources related to digital literacy present in public libraries as a means of help when taking part in digital literacy related activities. The results in Table 3 . indicate that half of the public libraries in this research use traditional printed guidelines and tutorials while only a quarter of libraries use digital guidelines and tutorials and multimedia Web tutorial of the Web page of the library. Generally, digital information sources and Web are underused and should be better support in acquisition of digital literacy knowledge and skills. There was only one alternative answer in the open part of the question material for workshops, but, clearly, this last answer does not provide any new information about use of information sources as a support to library activities enumerated in previous questions.

Q5 Frequency of receiving queries from users about information sources and activities related to digital literacy offered in library.

Table 4. Frequency of receiving queries from users about information sources and activities related to digital literacy offered in library.

$(\mathrm{N}=94)$
\begin{tabular}{|c|c|c|c|c|c|}
\hline Never & & & & Every day & \\
\hline 20 & 30 & 32 & 9 & 3 & $\mathrm{~N}$ \\
\hline 21,28 & 31,91 & 34,04 & 9,57 & 3,19 & $\%$ \\
\hline
\end{tabular}

Answers to this question present the real demand for information sources and activities related to digital literacy. User queries about information sources and activities related to digital literacy tend to be rather infrequent. Additional promotion of these specific information sources and activities could attract more users to public libraries as places offering education in digital literacy.

\section{Q6 Duration of offering activities related to digital} literacy.

Table 5. Duration of offering activities related to digital literacy. ( $\mathrm{N}=94)$

\begin{tabular}{|c|c|c|c|c|c|}
\hline $\begin{array}{c}\text { Less } \\
\text { than 1 } \\
\text { year }\end{array}$ & $\begin{array}{c}1-2 \\
\text { years }\end{array}$ & $\begin{array}{c}3-5 \\
\text { years }\end{array}$ & $\begin{array}{c}\text { More } \\
\text { than 5 } \\
\text { years }\end{array}$ & $\begin{array}{c}\text { We don't } \\
\text { offer such } \\
\text { activities }\end{array}$ & \\
\hline 6 & 19 & 18 & 35 & 16 & $\mathrm{~N}$ \\
\hline 6,38 & 20,21 & 19,15 & 37,23 & 17,02 & $\%$ \\
\hline
\end{tabular}

In spite of infrequent user queries about digital literacy information sources and activities in the previous question, over one third of public libraries in this research offer such sources and activities for longer than 5 years and over half of public libraries (in total) in this research offer such sources and activities for three years and 
longer which is encouraging and suggest successful history of education of uses in digital literacy. This is a strong argument when advocating libraries as places for education.

Q7. Topics offered in public library as part of digital literacy related activities.

Table 6. Topics offered in public library as part of digital literacy related activities $(\mathrm{N}=95)$ (multiple answers possible)

\begin{tabular}{|l|c|c|}
\hline & $\mathrm{N}$ & $\%$ \\
\hline Searching the Internet & 81 & 85,26 \\
\hline Searching the library online catalogue & 76 & 80,00 \\
\hline Use of PCs in the library & 76 & 80,00 \\
\hline E-mail & 62 & 65,26 \\
\hline Word processing & 60 & 63,16 \\
\hline Connecting devices to the Internet & 58 & 61,05 \\
\hline Use of social media & 50 & 52,63 \\
\hline Use of government information sources & 41 & 43,16 \\
\hline Graphical content editing & 41 & 43,16 \\
\hline $\begin{array}{l}\text { Database (professional and scientific information) } \\
\text { search }\end{array}$ & 40 & 42,11 \\
\hline Presentation editing & & \\
\hline Web page design & 39 & 41,05 \\
\hline Web don't offer such activities & 8 & 8,42 \\
\hline Other & 6 & 6,32 \\
\hline E-book design & 3 & 3,16 \\
\hline
\end{tabular}

High percentages of majority of answers in this question suggest versatility of public library user interests when seeking additional education about use of ICT. Learning how to use an Internet service in addition to more traditional skills like use of PC and word processing is dominating the current topic landscape in public libraries. The topics are easily adapted to the interests of library users and public libraries have always been very cooperative in providing support for self-learning, informal learning, or continuing learning.

Q8. Segments of public library users' lives would be improved if they had higher level of digital literacy.

Table 7. Segments of public library users' lives would be improved if they had higher level of digital literacy. $(\mathrm{N}=95)$ (multiple answers possible)

\begin{tabular}{|l|c|c|}
\hline & $\mathrm{N}$ & $\%$ \\
\hline Education & 82 & 86,32 \\
\hline Interaction with the government & 80 & 84,21 \\
\hline Preparation for search for a job & 78 & 82,11 \\
\hline Free time / hobbies & 76 & 80,00 \\
\hline Preparation for a workplace & 75 & 78,95 \\
\hline Informing oneself about health & 49 & 51,58 \\
\hline Growth of Internet economy (buying, selling) & 33 & 34,74 \\
\hline None & 1 & 1,05 \\
\hline
\end{tabular}

This question aimed at discovering segments of public library users', which would benefit from knowledge and skills in digital literacy. The results suggest that public libraries perceive a few segments as important in users' lives, which could lead to conclusion about the growing importance of digital literacy in one's life regardless of the segment of one's life.
Q9. Age of library users asking for content related to digital literacy.

Table 8. Age of library users asking for content related to digital literacy. $(\mathrm{N}=95)$

\begin{tabular}{|l|c|c|}
\hline & $\mathrm{N}$ & $\%$ \\
\hline Pre-school users & 0 & 0,00 \\
\hline Elementary school users & 28 & 29,47 \\
\hline High school users & 14 & 14,74 \\
\hline University students & 10 & 10,53 \\
\hline Young employees & 8 & 8,42 \\
\hline Middle aged users & 15 & 15,79 \\
\hline Elderly users & 19 & 20,00 \\
\hline
\end{tabular}

According to the results in Table 8, activities in acquisition of knowledge and skills in digital literacy have been sought by many generations of library users. Participation in such activities by younger generation of public library users could suggest lack of such activities in schools and universities, while participation of middle aged and elderly users could suggest insufficient quantity and intensity of such activities during their earlies education. Therefore, public libraries fill in these gaps perfectly by servicing many generations of users regardless of their educational background. What counts is that users are determined to become digitally literate citizens.

Q10. Cooperation of public libraries in carrying out digital literacy-oriented activities.

Table 9. Cooperation of public libraries in carrying out digital literacyoriented activities. ( $\mathrm{N}=94)$ (multiple answers possible)

\begin{tabular}{|c|c|c|}
\hline & $\mathrm{N}$ & $\%$ \\
\hline $\begin{array}{l}\text { With individuals from the Croatian elementary and high } \\
\text { schools }\end{array}$ & 42 & 44,68 \\
\hline With other public libraries in Croatia & 20 & 21,28 \\
\hline With schools in Croatia & 20 & 21,28 \\
\hline With other school libraries in Croatia & 19 & 20,21 \\
\hline No, all activities are carried out by our library alone & 19 & 20,21 \\
\hline We don't have this type of activity in our library & 16 & 17,02 \\
\hline Other & 10 & 10,64 \\
\hline With scientists (in general) & 9 & 9,57 \\
\hline With individuals from the Croatian universities & 8 & 8,51 \\
\hline With the Croatian Ministry of culture & 7 & 7,45 \\
\hline With scientific institutions in Croatia & 6 & 6,38 \\
\hline With other libraries outside Croatia & 2 & 2,13 \\
\hline With other high-education libraries in Croatia & 2 & 2,13 \\
\hline $\begin{array}{l}\text { With the Croatian Ministry of science, education and } \\
\text { sport }\end{array}$ & 1 & 1,06 \\
\hline
\end{tabular}

In cases in which public libraries do not have the necessary sources, knowledge, or adequate number of employees, they cooperate with individuals and institutions. The results in Table 9. show that public libraries cooperate most frequently with individuals from the Croatian elementary and high schools. It is rather surprising that public libraries have very infrequent cooperation with scientists and scientific institutions in Croatia. Ten public libraries chose the answer "Other": Microbit:content (irrelevant answer); different associations; associations like Croatianmakers, MakeX, WER; With the institute for development and innovations for youth $(2 \mathrm{x})$; volunteers - students; IRIM; only one librarian in the library doing all jobs; volunteers; private 
sector. All these answers except "We don't have this type of activity in our library" are positive for public libraries and library users counting on the former to offer them additional education activities they are missing otherwise. More experienced public libraries will be offering education in digital literacy to even more individuals in future and institutions will be in position to cooperate with them in this type of activities.

Q11. Is public library well equipped with information sources necessary for education of users about digital literacy?

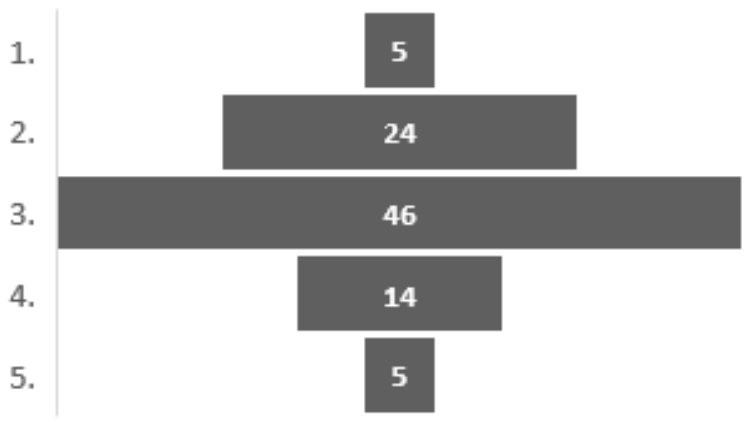

Figure 1. The degree to which public library is well equipped with information sources necessary for education of users in digital literacy. ( $1=$ The library doesn't have the necessary information sources at all; $5=$ The library has all the necessary information sources $)(\mathrm{N}=94)$

Public libraries in Croatia in this research were given an opportunity to estimate the degree to which they are well equipped with information sources necessary for education of users in digital literacy. On the scale from 1 to 5 they indicated that there is a space for improvement and that public libraries could acquire additional information sources (printed or digital) to support their digital literacy activities. One should have in mind that public libraries offer substantial number of versatile activities and that they should be equally prepared and equipped for all of them, which is extremely difficult task for the management of any public library.

Q12. Is public library well equipped with the ICT equipment necessary for education of users about digital literacy?

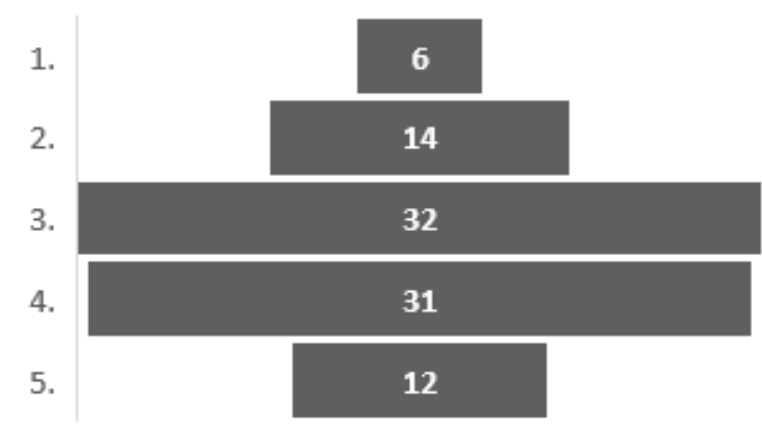

Figure 2. The degree to which public library is well equipped with the ICT equipment necessary for education of users about digital literacy. ( $1=$ The library doesn't have the necessary ICT equipment at all; $5=$ The library has all the necessary ICT equipment) $(\mathrm{N}=94)$
In comparison to answers in the previous questions, the situation with the ICT equipment in public library necessary for carrying out digital literacy activities is less than optimal but it is not bad to the extent that public libraries wouldn't be able to carry out the planned activities. Answers to the questions 13 and 14 provide more insight in segments of public libraries' operation, which could be improved.

Q13. How well is public library prepared to carry out digital literacy related activities by itself?

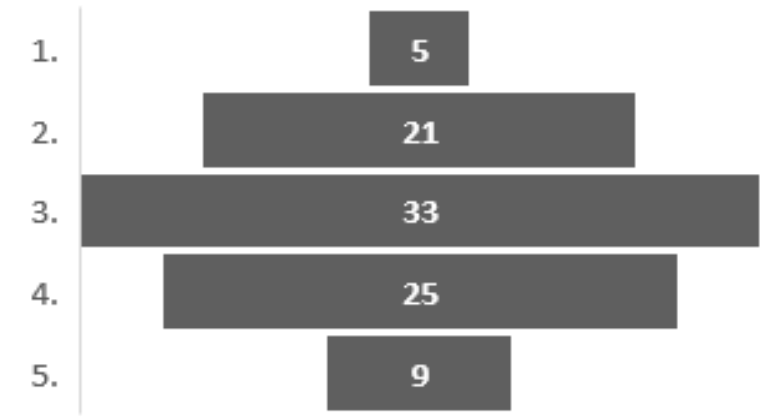

Figure 3. Preparedness of public library to carry out digital literacy related activities by itself. ( $1=$ Totally unprepared; Totally prepared) $(\mathrm{N}=93)$

Although it as an estimation, the answers in this scale indicate that situation is not bad it can be improved. This estimation includes all the elements necessary for carrying out digital literacy activities including confidence in abilities of librarians for participation in such activities. The overall situation is good, but it could be even better. Questions 11, 12 and 13 provide us with three very similar estimations that help us understand the degree to which public libraries could be included in digital literacy activities alone or in cooperation with others (Question 10.).

Q14. Improvements in public library in order for the library to be able to offer better information sources and activities related to digital literacy.

Table 10. Improvements in public library in order for the library to be able to offer better information sources and activities related to digital literacy. $(\mathrm{N}=95)$ (multiple answers possible)

\begin{tabular}{|l|c|c|}
\hline & $\mathrm{N}$ & $\%$ \\
\hline $\begin{array}{l}\text { More librarians included in digital literacy related } \\
\text { activities }\end{array}$ & 63 & 66,32 \\
\hline Additional financing of digital literacy related activities & 56 & 58,95 \\
\hline Additional education for librarians & 51 & 53,68 \\
\hline Newer personal computers & 42 & 44,21 \\
\hline Larger library space & 39 & 41,05 \\
\hline More personal computers & 37 & 38,95 \\
\hline New software for personal computers & 24 & 25,26 \\
\hline Faster Internet connections in libraries & 16 & 16,84 \\
\hline Other & 2 & 2,11 \\
\hline Nothing & 0 & 0,00 \\
\hline
\end{tabular}

This question aimed at collecting answers about concrete improvements public library would like to see in future in order to be able to offer better information sources and activities related to digital literacy. Most public libraries 
(two thirds) in this research need more personnel or librarians, as they feel understaffed. Public libraries also need better financing, additional education for librarians, newer personal computers (as well as more of them), larger library space, newer software, and faster Internet connections. All these improvements and requests are frequent in public libraries. More librarians, additional financing and larger library space are present in every research of quality of library operation. The positive side of these results is enthusiasm present in public libraries participating in this research, helping librarians to overcome usual inadequacies present in every public library. There were also two answers in category "Other": all the answers and more user needs (irrelevant answer). It is worth noting that not a single public library chose the answer "Nothing".

Q15. Opinion about library as a place of education and carrying out of digital literacy activities.

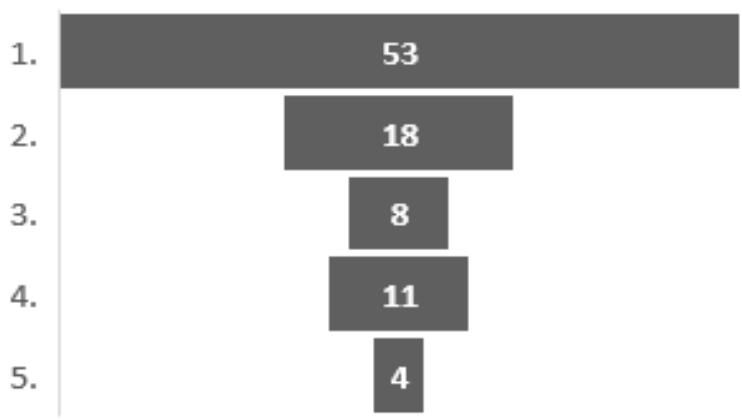

Figure 4. Opinion about library as a place of education and carrying out of digital literacy activities. ( $1=$ Totally positive; $5=$ Totally negative $)$ $(\mathrm{N}=94)$

The final question in the research aimed at finding out opinion of the participating public libraries as places of education and carrying out of digital literacy activities. The answers to this question were grouped on the positive side of the scale indicating that public libraries have positive attitude towards this question, which is a guarantee for the continuation of such activities in future.

\section{CONCLUSION}

Digital literacy has become one of the critical literacies for development of individuals and society in general. Customary places for acquisition of knowledge and skills related to digital literacy are schools and universities. However, not all students end their formal education with sufficient knowledge and skills necessary for rapid employment and advancement in career. In the world of emerging industry 4.0, individuals need continuing education to keep abreast of constant changes in society and to remain relevant on the labour market. As formal education system sometimes cannot provide all the necessary knowledge and skills, public libraries step in and offer additional information sources and activities, which will bring future workforce to employment and those seeking new job or just wanting to improve their knowledge and skills closer to their goal. The research in this paper showed that public libraries are active players in the educational arena. They understand what digital literacy means; they have solid resources to carry out digital literacy related activities. However, they face certain obstacles in carrying out their digital literacy related activities like lack of library staff, more financial means, larger space and equipment. In spite of these problems, public libraries remain relevant places for education for many generations of library users and they plan to remain so in the coming years.

\section{REFERENCES}

[1] D. Van der Westhuizen, G. Barlow-Jones. "The Role of Digital Literacy in the Academic Performance of First-Year Students in an Information Technology Course", Retrieved December 20, 2019.

from

https://www.researchgate.net/profile/Duan_Van_Der_Westhuizen/ publication/261725496_The_Role_of_Digital_Literacy_in_the_A cademic Performance of First-

Year_Students_in_an_Information_Technology_Course/links/559 $51 \mathrm{a} 4 \overline{8} 08 \mathrm{ae} 210 \overline{8} 6 \overline{\mathrm{d}} 1 \mathrm{f} 0 \overline{\mathrm{d}} 2 \mathrm{f} /$ The-Role-of-Digital-Literacy-in-the-

Academic-Performance-of-First-Year-Students-in-an-InformationTechnology-Course.pdf

[2] J. Sefton-Green, J. Marsh, O. Erstad and R. Flewitt. "Establishing a Research Agenda for the Digital Literacy Practices of Young Children: A White Paper for COST Action IS1410", 2015. Retrieved December 20, 2019. from http://digilitey.eu/wpcontent/uploads/2015/09/DigiLitEYWP.pdf

[3] P. Hummelgaard. "The jobs forecast is unsettled. It's time for a reskilling revolution", 2019, Retrieved December 5, 2019. from. https://www.weforum.org/agenda/2020/01/denmark-reskillingrevolution-future-of-work/

[4] F.J.L. Handley. "Developing Digital Skills and Literacies in UK Higher Education: Recent Developments and a Case Study of the Digital Literacies Framework at the University of Brighton, UK". Publicaciones, Vol. 48, pp. 97-109., 2018.

[5] "Framework for Information Literacy for Higher Education", $\begin{array}{llll}\text { Retrieved } & \text { December } & 20, & 2019 .\end{array}$ http://www.ala.org/acrl/standards/ilframework

[6] "Digital literacy, libraries, and public policy: Report of the office for information technology policy's digital literacy task force", Retrieved December 20, 2019. from https://districtdispatch.org/wpcontent/uploads/2013/01/2012_OITP_digilitreport_1_22_13.pdf

[7] "10 Digital Skills That Can Make Students Instantly Employable", Retrieved December 5, $2019 . \quad$ from https:/digitalmarketinginstitute.com/en-eu/blog/10-digital-skillsthat-can-make-students-instantly-employable

[8] "What are digital skills? A comprehensive definition for modern organisations", Retrieved December 5, 2019. from http://www.skillsoft.com/assets/whitepapers/Skillsoft whitepaper What-are-digital-skills-acomprehensive-definition.pdf

[9] “Digital Skills Toolkit", 2018. Retrieved December 20, 2019. from https://www.itu.int/en/ITU-D/DigitalInclusion/Documents/ITU\%20Digital\%20Skills\%20Toolkit.pdf

[10] "World Economic Forum, The Future of Jobs: Employment, Skills and Workforce Strategy for the Fourth Industrial Revolution", 2016. Retrieved December 5, 2019. from http://reports.weforum.org/future-of-jobs-2016

[11] "IFLA Statement on Digital Literacy", 2017. Retrieved December 5, 2019. from https://www.ifla.org/publications/node/11586

[12] "Continuing education", Retrieved December 5, 2019. from https://www.collinsdictionary.com/dictionary/english/continuingeducation 